\title{
Employing Green Roofs to Support Endangered Plant Species: The Eastern Suburbs Banksia Scrub in Australia
}

\author{
John Blair* (), Paul Osmond \\ Faculty of Built Environment, University of New South Wales, Anzac Parade, Kensington, New South Wales, Australia

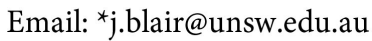

How to cite this paper: Blair, J. and Osmond, P. (2020) Employing Green Roofs to Support Endangered Plant Species: The Eastern Suburbs Banksia Scrub in Australia. Open Journal of Ecology, 10, 111-140. https://doi.org/10.4236/oje.2020.103009

Received: December 30, 2019

Accepted: March 27, 2020

Published: March 30, 2020

Copyright (๑) 2020 by author(s) and Scientific Research Publishing Inc. This work is licensed under the Creative Commons Attribution International License (CC BY 4.0).

http://creativecommons.org/licenses/by/4.0/

\section{(c) (i) Open Access}

\begin{abstract}
The purpose and context for the study relates to urban growth. Australian cities are experiencing particularly rapid urbanization, taking the form of land clearing to accommodate outward expansion as well as developing to higher densities in existing urban areas. Both forms of development degrade native biodiversity, resulting in loss of vegetation with the possibility that the remnant indigenous plants will become locally extinct. One endangered ecological community in Sydney, the Eastern Suburbs Banksia Scrub (ESBS), still survives along some sections of Sydney's heavily urbanized coastline. At the time of European settlement, the ESBS covered approximately 5300 ha, but it is now a highly fragmented 146 ha across 24 sites with some sites under imminent threat of development. Conservation legislation enacted by the state of New South Wales (NSW), Australia has declared the ESBS as critically endangered. Despite recovery plans, in 2016 the NSW Threatened Species Scientific Committee indicated that the community faces an extremely high risk of extinction in Australia in the immediate future. A practical option in the face of declining open space in our cities is to examine the potential of urban rooftops for conserving and propagating threatened or endangered flora. While there is a limited amount of international research on using green roofs for endangered plant protection, there is no information from Australia about how green roofs perform in this geographic region. The approach taken in this research has been firstly, to review the current academic and "grey" literature from a global perspective to identify options for conserving endangered flora on green roofs. We derive an evidence-based research protocol to be used to test the green roof environment in Sydney for propagating the endangered ESBS. We establish the general applicability of green roofs for protecting vanishing flora through the literature review and conclude that our research design will be a suitable framework for the task for
\end{abstract}


monitoring growth and germination performance over the ESBS community's development cycle, with the longer-term objective of establishing a viable rooftop seed orchard.

\section{Keywords}

Rapid Urbanization, Native Vegetation, Endangered Species, Green Roofs, Research Design

\section{Introduction}

Rapid urbanisation has been identified as a so-called "megatrend", with an estimated 1.5 million people being added to the global urban population every week. While most of this growth is occurring in Africa and Asia, Australia's rate of urban growth is among the highest in the developed world. The statutory government agency, Infrastructure Australia [1] has projected an additional 11.8 million Australian city dwellers between 2017 and 2046, equivalent to building a new Canberra-sized city every year for the next 30 years.

From a systems perspective, key environmental impacts of urban growth include an upsurge in consumption of resource inputs (energy, water, materials) and in production of detrimental outputs (air and water pollutants, waste) [2]. Further, land clearing to accommodate both outward expansion and internal densification degrades native biodiversity and supplants urban and peri-urban agriculture [3]. However, it should be noted that removal of vegetation is by no means restricted to urban development, and some authors [4] point out that land clearing remains the single greatest threat to terrestrial biodiversity in Australia. In the State of New South Wales (NSW) for example, clearing of native vegetation, predominantly for agriculture and mining, jumped $800 \%$ between 2013 and 2016. As at December 2018, 692 plant species were listed as "threatened", representing about $14 \%$ of the total number of native plants in NSW [5].

The above provides the context for a pragmatic approach to the conservation of one particular ecological community, the Eastern Suburbs Banksia Scrub (ESBS), which still survives along some sections of Sydney's heavily human-modified coastline. The ESBS was the first ecological community to be listed as endangered under the NSW Threatened Species Conservation Act 1995; this Act has been superseded by the NSW Biodiversity Conservation Act 2016, under which the ESBS is now listed as critically endangered. The ESBS has also been listed as endangered under the Australian Federal Government's Environment Protection and Biodiversity Conservation Act 1999. Both statutes required a recovery plan which led to the preparation of guidelines and management plans for a limited number of sites. The remnant ESBS faces threats from further urban development, weed invasion, fire and erosion. Despite a 2004 recovery plan and a 2009 vegetation management plan [6], only $2.7 \%$ of original coverage remains, spread across four coastal local government areas (Figure 1). The NSW Threatened 


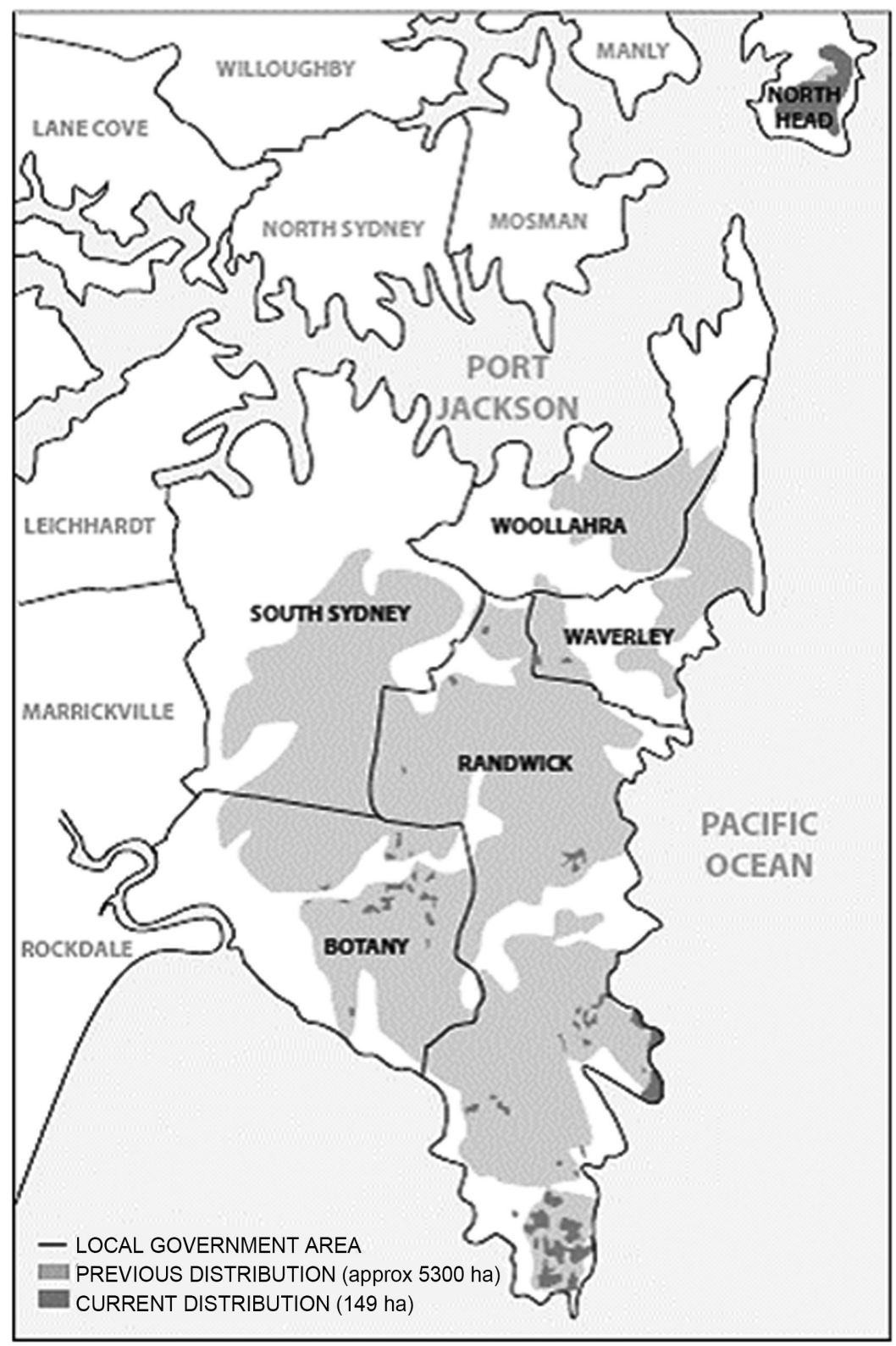

Figure 1. Location of ESBS remnants [6].

Species Scientific Committee has indicated that the community faces an extremely high risk of extinction in Australia in the immediate future [7] and, as noted above, the threat to the ESBS is not unique.

Protecting endangered species in their existing habitat in conditions of rapid development is inevitably going to be difficult. One pragmatic but innovative option is to expand our horizons to consider the untapped resource of our urban rooftops. Thus, the framework for this research is conservation biology and the main objective of this proposal is to examine the little remaining vacant space in our metropolises and specifically to evaluate the capacity of green roofs (GRs) to grow and sustain key ESBS species. An additional aim is to determine the ability of GRs more generally to help conserve endangered plant communities and spe- 
cies, acknowledging that there is a limit to the size of plants suitable for rooftop planting. In this way, it may be possible to shrink the human ecological footprint to a small degree.

\section{Green Roofs and Their Benefits}

Multiple environmental, social and economic benefits connected with GRs are widely reported in the literature, as summarized in Table 1. Several landmark studies have been conducted in the past including those by [8] who modelled the monetary benefits of installing green roofs in Toronto; the Centre for Neighbourhood Technology and American Rivers (CNTAR) which also focused on quantifying benefits [9]; the researchers [10] who compiled a professional guide to the design, installation and maintenance of green roofs; and the United States' General Services Administration (USGSA) [11]. The USGSA study was a meta-analysis of 200 research studies on the costs, benefits, challenges and opportunities of green roofs, and was accompanied by an original cost-benefit analysis and discussion of best practice. It is important to check the assumptions behind the studies that have attempted to monetize benefits. For example, [8] assumed that $100 \%$ of available roof space and all roofs over $350 \mathrm{~m}^{2}$ would be vegetated. Other research includes a study on stormwater quality from the UK [12]; a "state of the art" analysis of environmental benefits [13] and a white paper on the

Table 1. Key benefits of green roofs.

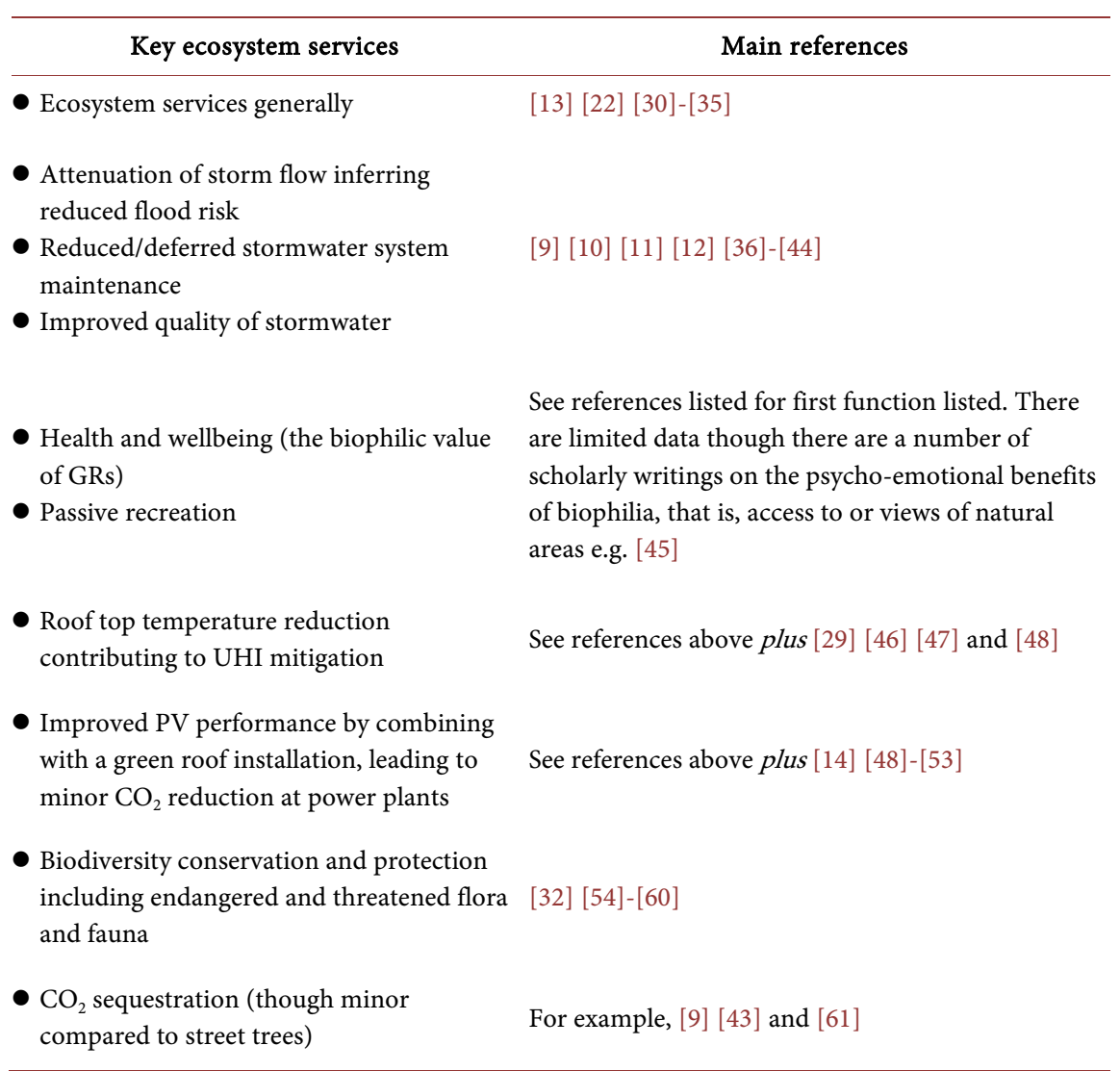


potential unintended consequences of reflective cool roofs, increasingly proposed as an alternative to more costly green roofs to mitigate urban overheating [14].

Collectively, the GR benefits cited in the international literature are wide-ranging. Reduced stormwater runoff together with improved water quality are common findings, although [12] as a rare exception, found high concentrations of heavy metals in runoff from an old GR in Manchester, England. Microclimatic effects include a contribution to reducing the urban heat island [13] [15] [16] and [17]. Using advanced simulation techniques, [15] found that $30 \%$ greenery coverage of the Darwin CBD (including tree canopy as well as GRs) would reduce local maximum temperatures by $2.66^{\circ} \mathrm{C}$ and $2.41^{\circ} \mathrm{C}$ with $5 \mathrm{~m} / \mathrm{sec}$ NW and SE winds, respectively. Installing green roofs alone on all buildings would result in a maximum temperature drop in the CBD of about $0.49^{\circ} \mathrm{C}$ and $0.53^{\circ} \mathrm{C}$ for the same wind speed and the same two wind directions respectively. These are not dramatic reductions and they lessen at lower wind speeds. On the other hand, researchers [18] using a heat index comprising temperature and relative humidity, found that a combination of green roof and green wall retrofits offered a distinctly helpful role in attenuating interior heat stress in residential buildings.

Green roofs reduce cooling and heating loads for the floors immediately beneath the roof [19] and [20] and some particulate atmospheric pollutants are adsorbed, while greenhouse gases as well as other gaseous pollutants are absorbed [21], $\mathrm{CO}_{2}$ being removed through photosynthesis. Biodiversity improvements are indisputable compared with conventional roofs. However, biodiversity protection and conservation of endangered flora have rarely been addressed in the GR literature compared with the research carried out on stormwater quality and detention, on building energy savings, or indeed on faunal biodiversity [22]. With the continued pace of research on GRs, however, there are recent signs of researchers investigating the capacity of the artificial environment of green roofs for biodiversity protection and conservation of endangered flora, as noted in Table 1.

Other somewhat less conspicuous benefits of GRs include noise attenuation [23], the potential for urban agriculture [24] and enhanced roof membrane durability. In the last case, the USGSA [11] suggests that a conservative estimate puts the average life of a GR membrane at 40 years compared with 17 years for a conventional roof. Green roofs' role in providing additional passive recreational space in dense urban settings is also valuable [25] and [19]. Site visits to several GRs in Sydney demonstrate that some are used as pleasant settings for passive relaxation. Figure 2 and Figure 3 are typical examples. It may be that one motivation of owners/developers is to provide social benefits on what would otherwise be an unused space. The perceived value-add for leasing space in the building may also have prompted some owners to absorb the extra construction and maintenance costs of GR installation. 


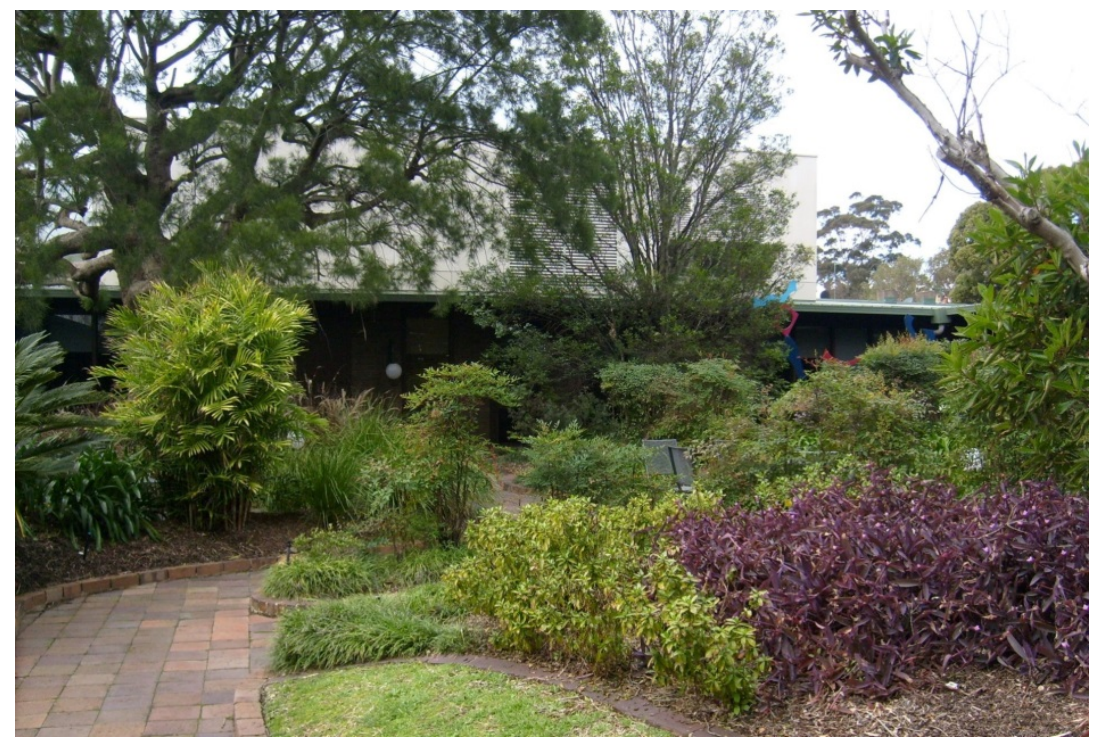

Figure 2. The Readers Digest Building in Surry Hills, central Sydney, a second floor intensive green roof (photo by authors).

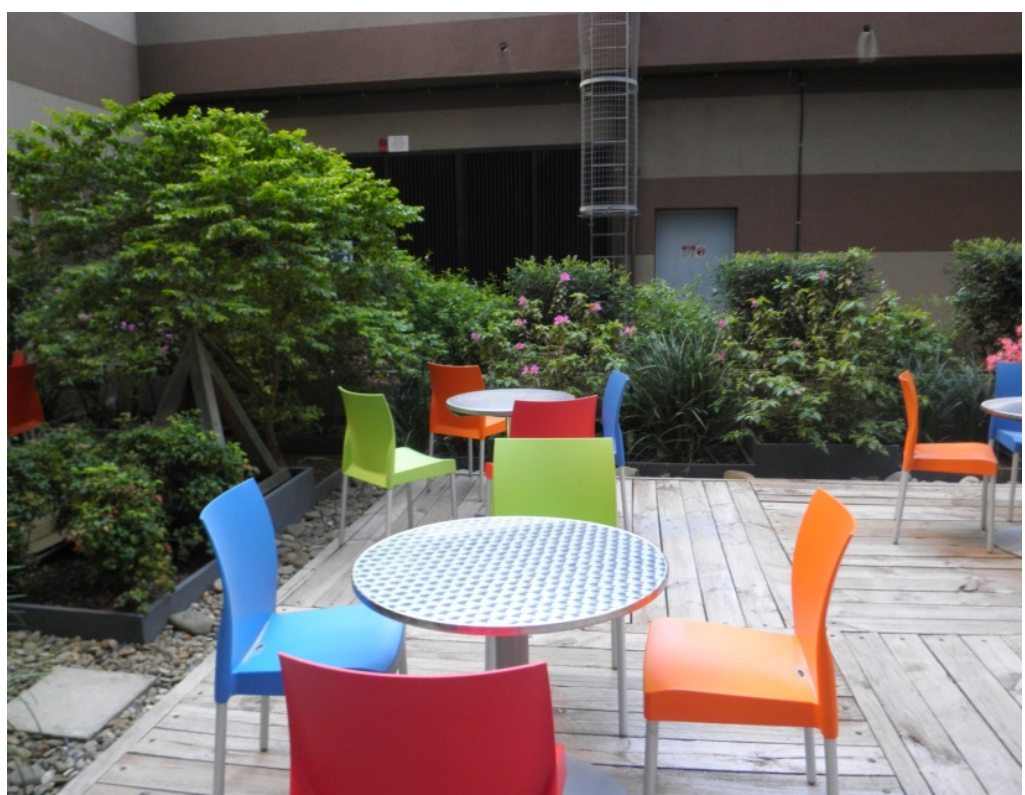

Figure 3. A semi-intensive green roof at the city campus of the University of New South Wales, O’Connell St, Sydney (photo by authors).

There are likely to be significant differences in outcomes from extensive as distinct from intensive roofs ${ }^{1}$ for the benefits listed [13] [26]. Moreover, GRs need to be implemented on a large scale for bio-physical benefits to be appreciable and some of those benefits could be obtained by other means [27]. For ex${ }^{1}$ For the purpose of this paper, intensive green roofs have a thicker substrate (typically $>200 \mathrm{~mm}$ ), generally support a much greater variety of plants including shrubs and small trees, require more maintenance and are designed for people to use. Extensive roofs are constructed on a substrate $<150$ - $200 \mathrm{~mm}$ deep and comprise a shallow layer of vegetation such as sedums, grasses and other groundcover species. In practice, green roof depth varies even within the same site and the extensive - intensive categorization is a continuum, as seen in Figure 3. 
ample, while the $\mathrm{CO}_{2}$ sequestration capacity of a $500 \mathrm{~m}^{2}$ extensive Sedum spp. green roof is measurable, it is negligible compared with planting a single medium size tree [9]. Furthermore, reducing roof temperatures through planting could be achieved equally effectively by using a high albedo surface or "cool roof" technique like reflective paint [28]. Recent research from Lawrence Berkeley National Laboratory using a 50-year life cycle costing framework, suggests they could cool our urban areas three times more effectively than green roofs per unit area [29]. On the other hand, [14] point to a series of unintended consequences associated with reflective roofs and pavements such as glare, the health impacts of higher levels of UV radiation and possibly reduced local precipitation.

Regarding the societal goal of reducing atmospheric $\mathrm{CO}_{2}$, GRs can reduce energy consumption in a low rise building as well as sequester carbon in plants and substrate, but there is a distinct carbon cost involved in installing GR components and maintaining the installation during their lifecycle. Japanese research [61] calculated that the carbon payback time ranged between 5.8 and 15.9 years across two scenarios. Most life cycle elements were encompassed by the researchers and the shortest payback period was represented by an irrigated plant, Festuca arundinacea (Tall Fescue).

\section{Australia's embrace of green roofs}

Green roofs in contemporary building design have a long history with precedents from Modernist architecture, such as the GR on Le Corbusier's Villa Savoye (circa 1929-1931), conceived as outdoor rooms extending the living space of the house [62]. During the 1970s and ' 80 s, France and Germany pursued the installation of GRs vigorously, reflecting a growing concern with sustainable building technologies. In the last 20 years, this interest has spread to Canada, the USA and the UK, with some installations gaining world-wide acclaim, such as the $4300 \mathrm{~m}^{2}$ installation retrofitted to the roof of the Chicago City Hall in 2001 [43] and the GR integrated into the design of the California Academy of Sciences Building in San Francisco in 2008 [63]. Significant drivers in parts of Europe and North America have been legislative requirements and a variety of incentives provided by governments to promote the inclusion of green roofs and walls in new construction and encourage retrofits to existing development [64].

Internationally, subsidies and non-financial support vary widely and often carry pre-conditions, for example in Chicago, where biodiversity specifications must be met before floor area bonuses are made available. Toronto's by-law mandating GRs is accompanied by grants of $\$ 75 / \mathrm{m}^{2}$ up to a maximum of $\$ 100,000$

(http://www1.toronto.ca/wps/portal/contentonly?vgnextoid=3a0b506ec20f7410

VgnVCM10000071d60f89RCRD) while in New York City, property tax credits of US $\$ 45 / \mathrm{m}^{2}$ up to US $\$ 100,000$ are available providing the GR covers a minimum of $50 \%$ of available rooftop space. The city is hoping to greatly expand the coverage of GRs through draft legislation presented to the NYC government in 
July 2018. The intention is to promote vegetation, photovoltaics and small wind turbines either in combination or individually to secure environmentally responsible activity on the City's roofs

(https://www.amny.com/news/green-roof-nyc-1.19912433).

In Australia, GRs have been less popular perhaps due to the perceived expansiveness of the physical environment, with its generous suburban landscape [62]. In the 1960s, a limited number of GRs were installed in Sydney, mainly on new apartment buildings, designed to extend domestic living space. A rare commercial example from that era is the 1967 Reader's Digest Building, featuring an intensive GR with exotic and Australian native plants, included as an outdoor 'retreat' for employees of the company (Figure 2, above).

Research on the bio-physical benefits of GRs has been conducted at several Australian universities, with the University of Melbourne emerging as a major centre, focusing on GR substrates, use of Australian native plants and temperature modification of building interiors [65]. This work is supported by Australia's first dedicated green roof demonstration, training and research facility (http://thegirg.org/burnley-green-roof/), established in 2012. The University of Western Sydney has completed research on stormwater quality and the evaluation of a mix of exotic and native plants and substrate mixes has been completed [66]. Researchers from the University of Technology, Sydney have examined the suitability of campus roofs for greening [67] and [68] as well as their urban agricultural potential [69]. Lastly, there is UNSW's exploratory move towards re-establishing a pair of derelict GRs on campus.

At local government level in Australian capital cities, policies are pitched at enabling GRs/GWs rather than prescribing them and any focus on biodiversity conservation is completely absent. The City of Sydney has a green roof policy and implementation plan [70] [71] with installation guidance and offers fast tracking of development applications for developers who wish to install rooftop vegetation. As reported in the Sydney Morning Herald on January 19, 2018, Sydney has 53 green roofs and an undisclosed number of green walls (https://www.smh.com.au/national/nsw/missed-opportunity-for-green-roofs-assydneys-apartment-boom-continues-20180118-h0k8pu.html).

The City of Melbourne and three other inner-city councils [72] have produced the Growing Green Guide, technical guidelines to encourage the transformation of Melbourne's roofs and facades into vegetated, leafy habitats [73]. The program identifies prime sites for the future development of GRs in inner metropolitan Melbourne, but the emphasis again is on encouragement, not concrete incentives, according to the City of Melbourne's 2017 update on greening the city, with green infrastructure still apparently viewed as an added extra rather than a necessary part of building design [74] and urban enhancement.

In the remaining four capital cities, Adelaide City Council points out that roof design in new developments should be structurally capable of facilitating sustainability functions such as GR installation (South Australian Department of 
Planning, Transport and Infrastructure 2012) [75]. Similarly, Brisbane's Plan for Action on Climate Change and Energy contains recommendations for market-led GR installation. It is not accompanied by any form of incentive [76] although a 2018 proposed change to Brisbane's City Plan will encourage developers to include rooftop gardens by exempting GRs from building height limits (https://theurbandeveloper.com/articles/developers-encouraged-to-incorporategreen-roofs-as-part-of-planning-changes-).

One of the smaller municipalities in the Perth metropolitan area has a water sensitive urban design policy in which green roofs are listed as a contributory element [77] and Darwin has a fleeting reference to green roofs in general discussion in its master plan [78]. However, a recent report commissioned by the city [15] presents convincing evidence that counterbalancing high ambient temperatures and the impact of urban heat islands is entirely feasible by adopting mitigation strategies like cool roofs and pavements, green roofs and urban greenery, shading and the use systems like water sprinklers and fountains [15]. Lastly, the local government of Australia's national capital of Canberra also refers to the value of green infrastructure and green roofs [79].

\section{Conservation Biology}

Natural ecosystems provide a critical range of services such as food, fuel, and timber; purifying air and water; sequestering and storing carbon; detoxifying and decomposing wastes; regulating climate; regenerating soil fertility; and pollinating crops. These ecosystem services have been estimated to be worth trillions of dollars annually [80] [82]. There is consensus in the scientific community that environmental degradation and destruction of many of the Earth's biota, is taking place on a catastrophically short timescale [82] [83] [84] [85]. Urbanization is a particularly significant threat but at the same time, urban green space, offers many opportunities for biodiversity conservation if it is managed with this objective in mind [57]. Ecological restoration [86] aims to slow the rate of species extinction and ecosystem service decline with two methods in particular. They are the conservation of currently viable habitat, and the restoration of degraded habitat, both forming part of the four-tier urban ecological hierarchy established by [87] for New South Wales. Actions might include erosion control, reforestation, removal of non-native species and weeds, revegetation of disturbed areas, and the reintroduction of native species. Also, part of the hierarchy is a third technique, the creation of new habitat, for example by using spaces previously uncolonized by the target species or indeed, any plant species at all, for example the roofs of buildings, the subject of this research proposal.

One researcher [88], noting a lack of basic information on how green roofs contribute to biodiversity, investigated the diversity of beetle communities, finding that it is the nature of the vegetation employed, in this case meadow grass species rather than forbs, that promotes faunal biodiversity, not so much the placement, age or height of the roof. However, [89] inventoried 51 GRs in 
Helsinki, Finland and found that substrate depth was a critical factor in structuring plant communities and vegetation abundance. It also was apparent that roof age was highly influential in structuring vegetation [89]. The plant communities changed from young sedum-moss dominated roofs and meadow-species communities chiefly characterized by the presence of sedums, into moss-dominated or almost pure meadow-species communities on older roofs. Meanwhile in northern France, [90] installed green roofs consisting of 176 vascular plant species, $86 \%$ of which were indigenous, across 115 roofs. They tested several variables, also finding that plant diversity was strongly related to substrate depth as well as green roof age, its surface area and height above grade, and even maintenance intensity at building scale [90].

While not formally endangered, bees are critical to human food security and their population is declining rapidly in some parts of the world. Field research in Illinois [32], indicated in the USA that urban green roofs may enhance populations of both native and exotic bees. While not a focus of their work, [89] noted a number of plant species that were in decline as well as the presence of host plants of threatened faunal species occurring in GR habitats. For example, Hylotelephium telephium is an important food plant for Parnassius apollo, a vulnerable butterfly species listed on the IUCN Red List of Threatened Species (http://www.iucnredlist.org/). The presence of listed and declining species on the roofs supports earlier findings [91], [92] that roofs can play a supportive role in the provision of habitat for rare and endangered fauna.

Like [93], [94] have argued for a more disciplined conservation planning to ensure the representation of a region's biodiversity by separating it from threatening impacts. Separation in the city is difficult because habitat is increasingly fragmented into smaller, numerous remnant patches [95] within a hostile matrix of urbanization. Species richness often declines too, as fragment area decreases [96]. As available land at grade diminishes, the significance of alternative types of urban green space for biodiversity conservation simultaneously grows [97], with the vacant space of flat and even moderately sloping rooftops, potentially taking on special value in inner city areas. Green roofs designed to facilitate habitat conservation on new developments could help resolve the invariable conflicts between ecosystem goals at ground level and economic aims [35], replenish space for greening and provide new opportunities for fulfilling our biophilic inclinations [98] [99]. With the majority of the world's population now city-dwellers-89.5\% in Australia according to https://tradingeconomics.com/australia/urban-population-percent-of-total-wb-d ata.html-many of us come into contact with nature solely within the urban fabric [100].

Green roofs can act as connectors which provide links between habitat fragments, more relevant to fauna than flora, but nonetheless the spread of organisms (and exchange of genes) between functioning fragments may occur. One of the few studies to evaluate the level of faunal connectivity between green roofs 
concluded that greater proximity facilitated a greater exchange of individuals between green roofs [101]. However, the habitat and corridor potential of a green roof needs to be evaluated in the context of its physical characteristics, microclimate and its relation to the urban landscape [31]. Other [102] accept that establishing a viable network of green roofs would support biodiversity by serving to shorten links between existing habitats but see this as an ideal. They caution that confounding issues of roof age, size and height above ground level, substrate depth and roof load bearing capacity as well as identifying roof tops in strategic locations to connect the fragmented networks of threatened fauna, may be difficult in practice.

Despite some scepticism about the value of corridors, the evidence from well-designed studies suggests that they are valuable conservation tools according to a detailed meta-analysis by [103]. Figure 4 shows schematically how green spaces such as backyards and green roofs could be planted with indigenous species to act as links between more significant fragments of native biodiversity. The diagram represents a progression from a pre-development condition through traditional development with parks and open space (light areas, centre image) to a situation in which backyards and green roofs (the light green areas in $\mathrm{RH}$ image) act more as ecological stepping stones than corridors between the parks and reserves. They are valuable in functioning as resting or foraging points for birds and invertebrates [38] and provide an opportunity—albeit small—for seeds to disperse, settle and germinate.

A citywide green roof strategy to support biodiversity conservation would also be supported by the numerous other ecosystem services offered by GRs, noted earlier in this paper. Such a strategy represents an important principle, using the ecosystem synergies provided by GRs to build on the positive aspects of city living and mitigate in a small way some of its negative aspects, such as air pollution and stormwater flows. Several other principles operate too:

- Sites which might be individually unimportant might become significant if they can be linked together into a web of habitat conservation sites;

- The greater the number of ecosystem connections, the greater the chance of robustness and resilience [105] thus strengthening the goal to improve current linkages as well as create new ones;
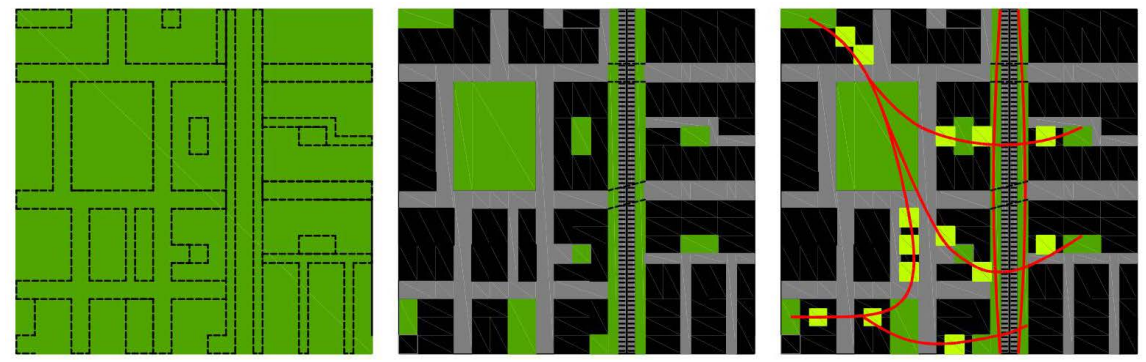

Figure 4. A possible progression for enhancing biodiversity in our cities [104]. From left: Pre-development; developed landscape with public open space; stepping stone spaces using green roofs and domestic gardens. 
- Full restoration of the pre-development plant communities is ecologically unrealistic in the city (particularly on rooftops with limited load-bearing capacity), so partial depiction or indication is a key goal [106];

- Implementing a meaningful GR strategy across the roofs of private residential, business, industrial premises and government and other public buildings is likely to be slow and incremental. While government agencies may wish to be seen in supporting a formal strategy, there will be two particular obstacles to overcome regarding non-government buildings. First, there is a lack of flat roofs in the large residential matrix of our cities outside the central business districts; second, business and industry will need to be willing to undertake both retrofits and new installations. It will depend heavily on the principle of reconciliation ecology, the last principle enunciated below [107]; and

- An important principle behind reconciliation ecology is enlisting community support by householders and businesses in ecological care, with the numerous bush care groups operating in the Sydney Region offering ample evidence of community interest in maintaining our native species. Green roof installation and plant maintenance would also entail reaching a compromise between human and non-human use of urban space to support biological conservation [107]. However, a green roof conservation initiative above grade and on private property would entail significantly higher levels of collaborative management than the typical ground level spaces in public ownership tended by residents.

\section{Green Roofs and Flora Conservation}

\subsection{International Experience}

There has been much international research in relation to fauna and green roofs, for example work by [108] regarding invertebrates; the colonization of GRs by beetles [55]); the positive effect of GRs on populations of both native and exotic bees [32]; the use of GRs as nesting sites for birds [109] and [110]; a year-long comparison of avian use of green roofs versus nearby conventional roofs by [111], and a study in Sydney, Australia by [59] which showed that green rooftops host up to three times the number of invertebrates and twice as many invertebrate taxa compared with bare roofs.

Research on the protection and enhancement of endangered and threatened flora is starting to emerge in the recent literature although at this point there appears to be no information from Australia on how green roofs perform in relation to endangered plant protection. Research on GRs in Australia has generally focused on optimising their physical benefits such as providing stormwater detention, passive recreation, microclimate modification and heating/cooling energy reduction to the neglect of plants as the key biological variable. Thus, the response to the conventional objective of gaining plant cover on the target roof has been to install vegetation known to perform adequately on rooftops, such as Sedum species, with minimal consideration given to the functional capacity of 
the plants [33].

However, recent studies from several countries have found that local species will flourish on extensive green roofs as well as, if not better than a low-diversity mix of cosmopolitan succulents like Sedum spp [108] [112]. Researchers like [113] for example, evaluated four different types of vegetation for their stormwater attenuation capacity and found that sedum spp. showed the largest amount of water runoff and was the only species group with more water runoff than the bare ground. However, [114], found that many North American prairie and grassland species, subject to harsh growing conditions in their natural habitats, will flourish on extensive green roofs and there can be significant additional maintenance costs of maintaining non-native vegetation types [115]. These might include the fertilizer, pesticides and significant irrigation needs of using temperate climate species for planting in the hot desert environment of the United Arab Emirates. The researchers also noted that native plants also help to restore wildlife by providing food and shelter for local fauna.

In Japan, researchers successfully propagated 13 plant species, four of which were classed as threatened [54], from the Jogasaki seacoast in Japan and planted them in three kinds of substrate on a newly constructed green roof at a nearby coastal location. The researchers pointed out that a complete understanding of the natural habitat of the native plants and replicating it carefully was critical to successfully simulating a local landscape on the green roof. Some years earlier, [116] in arguing for natural habitats, found the key to maintain populations of some rare species was to preserve the top layer of natural substrate, seed bank and soil organisms, for subsequent installation on the roofs of new developments.

Urban habitats can harbour self-sustaining populations of threatened or endangered native species. They are not likely to be a complete substitute for the functionality of the original ecosystem [100] although recent work by [117] highlights the relative importance of small, isolated habitat patches for biodiversity protection and show that they often have unique ecological and environmental characteristics. Functional diversity is strongly associated with the provision of ecosystem services and is a useful concept for designing the type of ecosystem that might be found on GRs, including providing opportunities to incorporate threatened local species [118]. Functional traits are defined, for example, by plant height, longevity, leaf area, succulence and flowering time. Inclusion of threatened or endangered indigenous plants with desirable traits on a green roof could meet the dual objectives of maximising ecosystem services and conserving flora. Preservation of threatened species thus becomes one way in which the principle introduced above of indication [106] together with skilful design may be implemented on urban rooftops.

The biodiversity research in relation to fauna conducted on green roofs can offer a degree of guidance on how to manage endangered flora, although most of the research has focused on locally abundant species. Researchers [113] in earlier 
research point out that the harsh growing environment of extensive GRs tends to restrict the range of plant species used but suggest from their research on forbs, sedum and grasses, that a greater functional diversity of vegetation provided more resilience to drought than a monoculture and was also rated higher from an aesthetic viewpoint.

Surprising performance improvements in growth rates and vegetation abundance in the local species has been found by [108], using species such as Carex argyrathra and C. nigra as opposed to industry standard green roof succulents, Sedum acre and Sedum spurium. Perhaps Sedum vegetation is popular because it is easier to install, easily modularised and relatively cheap. Quoting [108]: "the problem is that Sedum plants aren't really performing on green roofs... They're just there." Apart from not absorbing water as efficiently as other species, at certain times of the year Sedum actually absorbs heat instead of reflecting it [119]. Thus, a broad conclusion from the literature is that indigenous species which thrive in shallow soils, tolerate drought and are adapted to high winds, extreme temperatures and intense sunlight, particularly dry grassland, coastal, and alpine floras [120] are well suited to green roof installation though [121] point out that flora which does not fall into this category may be best conserved at grade until further knowledge is accumulated.

Another frequent theme is the need to match substrate depth and nutrient quality with the desired plant species [108]. Some research [122] has found that found that response to higher levels of organic matter was different for different species, and that species from a nitrogen-rich habitat tended to be encouraged by a high nitrogen content. Similarly, [109] working on green roofs in Zurich, Switzerland, has shown that use of natural soils can benefit biodiversity with useful implications for sustaining endangered species. Hence roof substrate nutrient status needs to be carefully considered in using local indigenous species, whether natural or manufactured growing media are selected. However, Australia has a uniquely high proportion of nutrient-poor soils to which much of the continent's native flora is adapted, which augurs well for the transfer of flora to GRs [123].

Equally critical is the need to consider the micro-fauna associated with green roofs. [124] quantifying the total microbial biomass and fungal levels in roof substrates and park soils, finding that park soils had greater microbial biomass and bacterial to fungal ratios than green roof substrates in New York. Microbial levels may influence plant functionality and the authors suggest that microbes and fungi on green roofs may be a functionally underestimated component of these systems. The same principle was emphasized by [125] in research on the immensely positive role of microbes in GR installations, noting that plants in natural habitats benefitted from interactions with the fungi and bacteria of the local microbiome and demonstrated improved means of survival and productivity. Clearly, careful investigation of this issue is needed so as to achieve the best possible outcomes for the ESBS on green roofs. 


\subsection{The Endangered Community of the Eastern Suburbs Banksia Scrub}

The ESBS is confined to the coastal suburbs of Sydney [126] and is a shrub-dominated and largely sclerophyllous heath community on nutrient-poor Aeolian dune sand. The ESBS consists of a minimum of 63 plant species and is near-extinct as an ecological community [127]. Common species in the ESBS community include over-storey 4 - 5 metre trees like the Heath-leaved Banksia (Banksia ericifolia), Old Man Banksia (B. serrata)—see Figure 5 and Coast Teatree (Leptospermum laevigatum); shrubs and ground cover species like Epacris spp., Pink Wax Flower (Eriostemon australasius), Variable Sword Sedge (Lepidosperma laterale, Tree-Broom heath (Monotoca elliptica) and Grass Trees (Xanthorrhoea resinifera). The ESBS is a predominantly fire-adapted community, highly dynamic and readily regenerates from re-sprouting and germination from the soil seed bank [6] [128] and [129].

The NSW Scientific Committee is currently reviewing a proposal to expand the definition of the ESBS to include certain vegetation communities near Bundeena, a southern suburb in Sydney surrounded by the Royal National Park [55] [130]. Local ecologists [131] suggest the endangered ecological community is regarded as particularly vulnerable to climate change due to its very limited north-south range and that ESBS remnants could cease being viable at remaining sites. Rather than focus on impacts per se, the authors applied a climate adaptation approach to conservation assessment through a case study at Queen's Park in inner-eastern Sydney. The authors concluded that new options for managing the site were needed, although using roof tops was not considered by the researchers or local stakeholders.

At the time of European settlement in 1788, the ESBS covered approximately $5300 \mathrm{ha}$, but it is now a highly fragmented 146 ha across 24 sites (Figure 4). Less than $3 \%$ of its original area remains and several small fragments are under imminent threat of development and exhibit quite high levels of degradation [132] [127]. A July 2018 update by the NSW Office of Environment and Heritage) (https://www.environment.nsw.gov.au/threatenedspeciesapp/profile.aspx?id=10 2577) indicates that after a prolonged period of greater than 15 years without fire

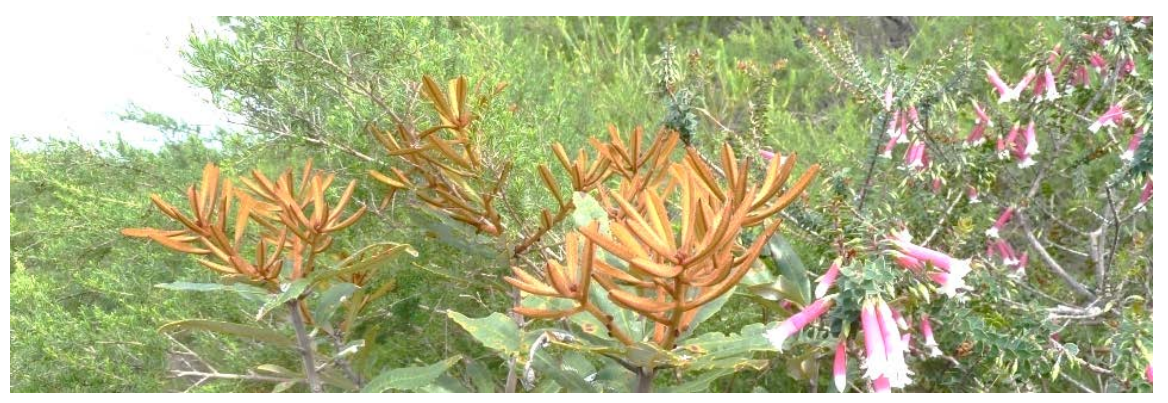

Figure 5. Banksia integrifolia (Old Man Banksia) and Epacris longifolia (Native Fuchsia) at Malabar Headland, a significant ESBS reserve. Image from Friends of Malabar Headland, http://malabarheadland.org.au/. 
or similar disturbance, the floristic composition and vegetation structure becomes simplified with a few species dominating the standing vegetation. The update also indicates that six priority sites have been declared for active management, which will include prescribed burns.

Dealing with the ESBS's status involved a recovery plan which was approved in 2004, followed by best-practice guidelines [6] and management plans for a limited number of sites. The degree of regeneration from the persistent seed bank following restoration at one of the medium size sites was remarkable according to [133]. The total number of native species increased only slightly over the six years (2001-2007) from 31 to 35 species, but a dramatic increase in abundance occurred across the site [127] and [134].

The removal of weeds or heavy shade was sufficient to trigger germination of a range of species in most of the managed quadrats, although germination still occurred in untreated plots without the addition of seeds. Practitioners also found that discarding the thick layer of leaf litter was important in that it revealed the more natural Aeolian sandy soil and simultaneously removed weedy and nutrient-rich top soils. This is an important finding given the intention to raise species indicative of the ESBS on trial green roofs in coastal Sydney, and given that plant resilience in the ESBS's case has been unusually good [133]. It is a characteristic that raises confidence of achieving conservation objectives in the relatively testing environment of green roofs.

\section{Proposed Research}

The research should be long term to allow plant conditions and characteristics to be monitored, and especially to observe a full cycle of seed planting and germination, growth into young seedlings, maturation, further seed generation by the maturing plants and natural germination. The research in this case would have the overall goal of supporting Objective 3 of the ESBS Recovery Plan which is to "To restore, and where practical, connect and enlarge remnants of ESBS through appropriate management" [135] and help to combat the apparent on-going loss of species and diminishing gene pool in some fragments of the ESBS [127]. Such research is also applicable broadly to green roofs and biodiversity conservation as well as offering more general ecosystem benefits and will necessitate cross-disciplinary contact among UNSW researchers as well as collaboration with external industry, government and community partners.

\subsection{Detailed Research Objectives}

The overall goal of the research is to establish a rooftop seed orchard of ESBS species to support consolidation of existing remnant sites, possible revegetation of new sites and potential supply to the local domestic garden market by the nursery industry. A series of detailed objectives follow:

1) Establish the ability of green roofs to act as a conservation medium and seed bank for a range of species within the ESBS community; 
2) Establish whether GRs are able to mimic natural conditions at ground level to determine the possibility of expanding their role more generally in the conservation of threatened and endangered species;

3) Develop the GRs as new ESBS sites to provide plants representative of the community and track their functioning on natural and artificial substrates of different depths;

4) Compare the functioning of the representative plants on the GRs against identical species at ground level remnant sites;

5) Trial the re-introduction of species absent from on remnant sites;

6) Fire regimes may influence over storey and understorey interactions and floristic composition generally [136]. Since some ESBS species are sensitive to competition by more vigorous native plants like Acacia spp. which are no longer controlled by fire, use the GR sites to introduce species easily crowded out or those that are reproduced in fire events;

7) Encourage species of the ESBS that do not form persistent ground-based seed banks;

8) Test the extent to which GRs can act as stepping stones for nectarivorous birds and insects (e.g. native bees) that may reinforce pollinator functions.

\subsection{Cultivation Principles}

The research involves designing a biotope or habitat of small-scale spaces on the GRs [137]. The researchers note that the key to success lies in examining site conditions carefully, possessing detailed knowledge of the species to be transferred to the GRs, acknowledging the small-scale characteristics that occur in the natural environment which provide niches for various forms of wildlife and paying attention to soil and microbial composition. The guiding principle would be to match conditions on the green roof closely with those enjoyed by the natural community [31] [138] and [120]. If this is achieved, it may become possible to replicate "unique ecological processes and ecological linkages in the space" [137]. Other cultivation principles that need to be borne in mind for the preparatory period for the research are summarized in Table 2.

\subsection{Installation Protocol}

The proposed site for the research consists of two $72 \mathrm{~m}^{2}$ roofs at first floor level, 4 metres above ground, on the University of New South Wales Kensington campus in Sydney. In addition to installing a safe external access to both roofs and providing GR infrastructure by way of waterproof membranes, drainage layers, root barriers and substrate, a number of other measures, chiefly physical, will need to be implemented as part of the GR experimental design. They are summarized below in Table 3.

\subsection{Monitoring Plant Performance}

Both plant and faunal characteristics must be monitored to gauge achievement 
Table 2. Cultivation principles for the ESBS and green roofs.

Cultivation principle

Relationship between substrate depth and fertility and plant abundance

Test ground level soil mantle before installation on the GR

Test landscape materials for toxins

Fine landscaping details

Substrate depths

Maximise ecosystem services

Irrigation

Select plant species

Cultivation guidelines

Implementation and outcomes

\section{Commentary}

This relationship was pointed out by [90] and [109] but may not apply to the ESBS since lush vegetation can exist on infertile and thin sands. Nevertheless, the key should be to match conditions on the GR closely with those enjoyed by the natural community, a factor likely to be critical to success [31] [138] and [120].

The principle of matching substrate depth and characteristics, noted immediately above, should also be applied to the soil micro-organisms and fungal populations of the ESBS Aeolian sand mantle to ensure representative communities are included in the GR substrate [124].

Landscape materials should be checked for toxins (see Installation Protocol below and Table 3).

Employ features on the GR found at grade such as rocks and tree branches to provide suitable microclimates as well as shade and sunny areas to encourage plant (and faunal) diversity [60]. Features like tree branches may need to be fabricated from lightweight materials to minimise roof loads and large rocks will need to be avoided.

Vary substrate depths in order to assess the ESBS community's response to this variable.

The planting design should attempt to increase the functional diversity of species to amplify ecosystem output, while being aware of GR limitations regarding substrate depth.

One researcher's findings [138] regarding improved plant survival with supplementary watering do not apply to Sydney's rainfall or the drought-adapted nature of the ESBS. However, one test cell may be irrigated for experimentation purposes.

Select plant species to reflect concerns about the lack of fire regimes, species which have difficulty forming soil seed banks and those plants which are no longer present on remnant sites. Selection to be conducted in association with Randwick Community Nursery and the School of Biological, Earth and Environmental Sciences at UNSW. There is an overarching limit on substrate depth and plant height dictated by the roof load-bearing capacity.

Prepare cultivation guidelines including the need for hand weeding and for collecting and germinating seed to test the viability of green roofs as seed orchards.

Tracking progress in achieving objectives will require a detailed monitoring plan (see Section 5.4 below).

Table 3. Installation process.

\begin{tabular}{|c|c|}
\hline Installation element & Comments \\
\hline Establish the test modules & $\begin{array}{l}\text { Following infrastructure installation: } \\
\text { 1) Subdivide the roofs into test modules (see Figure 6); } \\
\text { 2) Select suitable species from the ESBS community for planting; }\end{array}$ \\
\hline Select substrates & $\begin{array}{l}\text { 1) Select both natural and artificial substrates, e.g. one directly from an ESBS site, an artificial aggregate version of } \\
\text { the natural substrate and an industry manufactured substrate, each at } 3 \text { different depths e.g. } 50 \mathrm{~mm}, 100 \mathrm{~mm} \text { and } \\
150 \mathrm{~mm} \text {; } \\
\text { 2) Discard rich leaf litter; } \\
\text { 3) Note comment in } 5.1 \text { regarding avoidance of materials which may contain hazardous or toxic substances. }\end{array}$ \\
\hline Test soils for lead content & $\begin{array}{l}\text { Many inner suburban Sydney soils still contain lead particles from the era of lead in petrol. This may be a factor in } \\
\text { selecting substrate options for the test beds } \\
\text { (https://www.smh.com.au/national/nsw/lead-levels-in-sydney-soil-dangerously-high-20170119-gtuea6.html). }\end{array}$ \\
\hline $\begin{array}{c}\text { Test landscape } \\
\text { materials for toxins }\end{array}$ & $\begin{array}{l}\text { Landscape materials should be checked for toxins, eg test cell edging, whether timber or plastic. Non-natural } \\
\text { substrate materials should similarly be checked since not all substrate will be obtained from in-situ ESBS remnants } \\
\text { (https://www.betterhealth.vic.gov.au/health/HealthyLiving/copper-chrome-arsenic-cca-treated-timber). }\end{array}$ \\
\hline
\end{tabular}

of objectives. Monitoring is a major undertaking in the research although the location of the GRs at UNSW is a major logistical advantage for the researchers. 


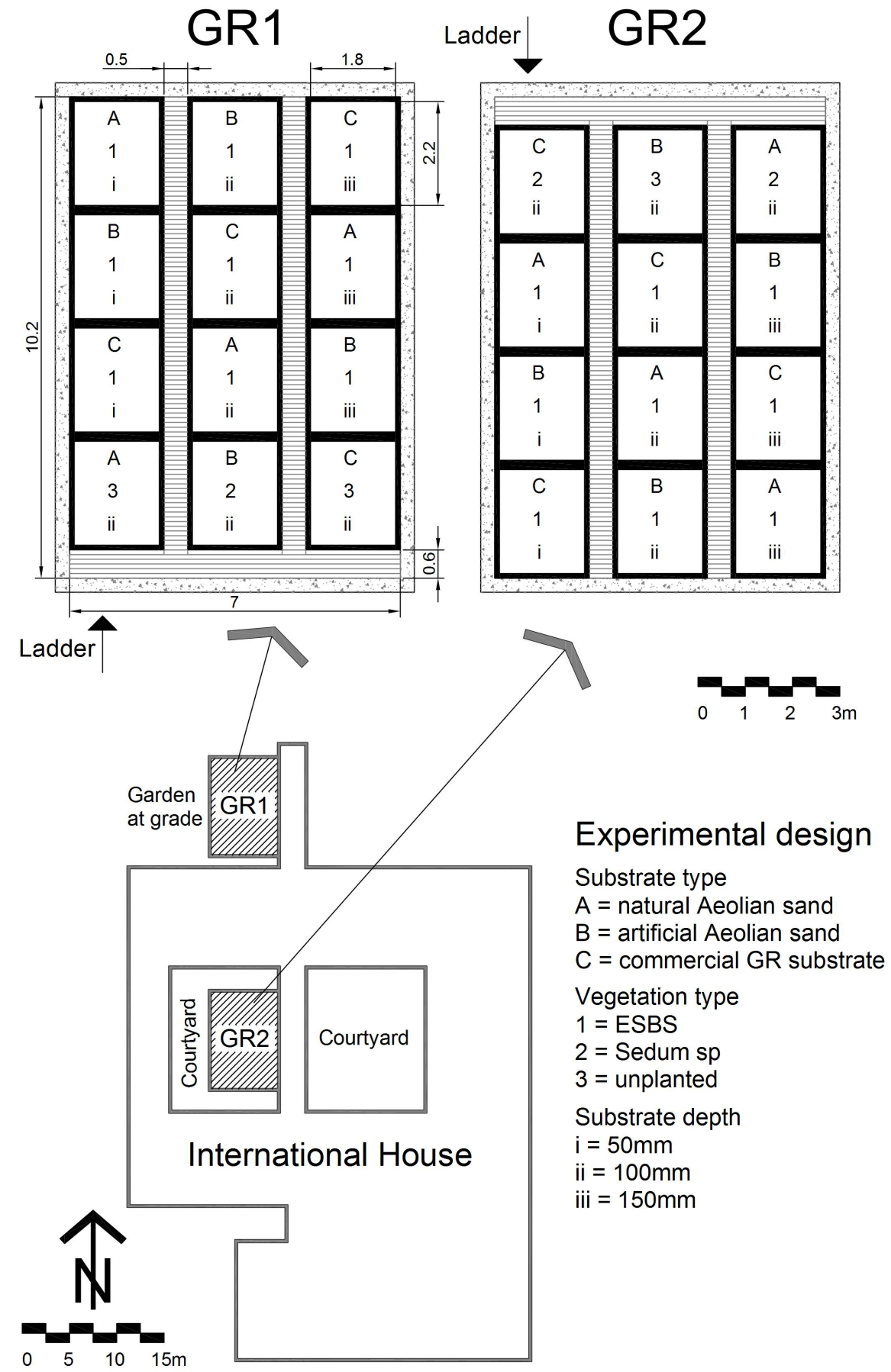

Figure 6. Experimental design for the ESBS green roof project at International House, University of New South Wales [104].

Seed will need to be collected and germinated to assess ESBS species' reproductive viability, and indices developed to assess survival, viability and growth and checked against performance benchmarks such as leaf area index, plant coverage and plant abundance. Volunteer plants appearing on the two experimental roofs will also be identified and monitored and will either be left in situ or removed if they appear to be crowding out the ESBS. Performance comparisons will be 
conducted with natural remnant populations and benchmarked against at least two of the remnant species locations and an appropriate frequency of field inspection undertaken. Equipment will also need to be installed for monitoring soil moisture and insolation levels while soil microflora will need periodic sampling [124]. Key performance indicators will also be constructed to measure the achievement of objectives, such as germination rates/percentage, viability and growth rates of seedlings.

The GRs attractiveness to fauna will also be monitored through data collection and a set of suitable diversity indices developed to evaluate faunal biodiversity (e.g. avian, reptilian, invertebrate) in collaboration with research students from the School of BEES at UNSW. These parameters will also be compared against two of the remnant species locations as with the floral performance tests and again with the frequency of check depending on the target of the inspection. Species richness would use the Shannon diversity index and the Simpson dominance index, both of which have been the most widely accepted measures of ecological diversity for the past fifty years [139] [140].

\section{Conclusions}

Planetary ecosystems provide a wide range of services both to humanity and to life in general, estimated to be worth trillions of dollars each year. Green roofs contribute multiple benefits to these services, including reducing stormwater run-off, moderating heating and cooling loads, carbon sequestration and storage, aesthetic and passive recreation opportunities and biodiversity conservation. It is the last named area that this paper is concerned about and there is growing realization that GRs may offer many opportunities for biodiversity conservation if they are managed with this objective in mind. Thus, researchers like [54] [109] and [138] are raising their objectives from simply obtaining bio-physical benefits from plants on GRs to selecting those which favour flora and fauna conservation, thus extending the function of rooftops as a vehicle for greening. At the same time, such research is showing how the difficulty of safeguarding threatened or endangered flora and fauna at ground level in our urban areas can be countered by harnessing currently vacant spaces on GRs.

In the absence of any Australian material focused on using GRs to rescue threatened or endangered flora, our research proposes to manage a currently threatened community of native Australian plants and support them using GRs. Our expected outcomes are both research and application related. Research-related findings include clarifying what optimum green roof properties might be in relation to, for example substrate thickness and biophysical properties and irrigation regimes for growing selected ESBS species. Outcomes would also include performance parameters for selected ESBS species on green roofs, including germination rates, viability, growth rates and vigour; the capacity of green roofs to provide ESBS seed orchard services and GR performance vis a vis invertebrate, vertebrate and avian faunal biodiversity. 
Application related outcomes consist of the provision of seeds for distribution to the four local Councils that still have remnants in their area and to other relevant stakeholders, for example the nursery and garden industry. In the longer term, the research could result in the removal of the ESBS from the endangered communities list.

\section{Conflicts of Interest}

The authors declare no conflicts of interest regarding the publication of this paper.

\section{References}

[1] Infrastructure Australia (2018) Future Cities: Planning for Our Growing Population, Commonwealth of Australia.

[2] Güneralp, B. and Seto, K.C. (2008) Environmental Impacts of Urban Growth from an Integrated Dynamic Perspective: A Case Study of Shenzhen, South China. Global Environmental Change, 18, 720-735. https://doi.org/10.1016/j.gloenvcha.2008.07.004

[3] Pauleit, S., Ennos, R. and Golding, Y. (2005) Modeling the Environmental Impacts of Urban Land Use and Land Cover Change-A Study in Merseyside, UK. Landscape and Urban Planning, 71, 295-310. https://doi.org/10.1016/S0169-2046(04)00083-0

[4] Gibbons, P. and Lindenmayer, D.B. (2007) Offsets for Land Clearing: No Net Loss or the Tail Wagging the Dog? Ecological Management \& Restoration, 8, 26-31. https://doi.org/10.1111/j.1442-8903.2007.00328.x

[5] NSW Office of Environment and Heritage (2018) Threatened Biodiversity Profile Search https://www.environment.nsw.gov.au/threatenedspeciesapp/profile.aspx?id=10257

[6] NSW DECC, Department of Environment and Climate Change (DECC) (2009) Best Practice Guidelines Eastern Suburbs Banksia Scrub. NSW Department of Environment and Conservation, Hurstville.

[7] NSW Threatened Species Scientific Committee (2016) Notice of and Reasons for the Final Determination.

https://www.environment.nsw.gov.au/resources/threatenedspecies/determinations/ FDESBSCEEC.pdf

[8] Banting, D., Doshi, H., Li, J. and Missios, P. (2005) Report on the Environmental Benefits and Costs of Green Roof Technology for the City of Toronto. Ryerson University, Toronto.

[9] Center for Neighbourhood Technology and American Rivers (2010) The Value of Green Infrastructure. CNT and American Rivers, Washington DC.

[10] Snodgrass, E. and McIntyre, L. (2010) The Green Roof Manual: A Professional Design Guide to Design, Installation and Maintenance. Timber Press, Portland, Oregon.

[11] US General Services Administration (2011) The Benefits and Challenges of Green Roofs on Public and Commercial Buildings. USA General Services Administration, Washington DC.

[12] Speak, A.F., Rothwell, J.J., Lindley, S.J. and Smith, C.L. (2014) Metal and Nutrient Dynamics on an Aged, Intensive Green Roof. Environmental Pollution, 184, 33-43. 
https://doi.org/10.1016/j.envpol.2013.08.017

[13] Berardi, U., Hosein, A., Hoseini, G. and Hoseini, A.G. (2014) State-of-the-Art Analysis of the Environmental Benefits of Green Roofs. Applied Energy, 115, 411-428. https://doi.org/10.1016/j.apenergy.2013.10.047

[14] Yang, J., Wang, Z. and Kaloush, K.E. (2013) Unintended Consequences: A Research Synthesis Examining the Use of Reflective Pavements to Mitigate the Urban Heat Island Effect. Arizona State University National Center of Excellence for SMART Innovations, Tempe.

[15] Santamouris, M., Hadad, S. and Synnefa, A. (2018) Heat Mitigation Program Darwin, Northern Territory. University of NSW and Government of Northern Territory, Sydney, Australia.

[16] Santamouris, M. (2014) Cooling the Cities-A Review of Reflective and Green Roof Mitigation Technologies to Fight Heat Island and Improve Comfort in Urban Environments. Solar Energy, 3, 682-703. https://doi.org/10.1016/j.solener.2012.07.003

[17] Peng, L. and Jim, C.Y. (2013) Green-Roof Effects on Neighbourhood Microclimate and Human Thermal Sensation. Energies, 6, 598-618.

https://doi.org/10.3390/en6020598

[18] Feitosa, R.C. and Wilkinson, S.J. (2018) Attenuating Heat Stress through Green Roof and Green Wall Retrofit. Building and Environment, 140, 11-22. https://doi.org/10.1016/j.buildenv.2018.05.034

[19] Li, W.C. and Yeung, K.K.A. (2014) A Comprehensive Study of Green Roof Performance from Environmental Perspective. International Journal of Sustainable Built Environment, 3, 127-134. https://doi.org/10.1016/j.ijsbe.2014.05.001

[20] Liu, K. and Baskaran, B. (2003) Thermal Performance of Green Roofs through Field Evaluation. NRCC-46412, National Research Council Canada, Ottawa.

[21] Bennett, J.H. and Hill, A.C. (1973) Absorption of Gaseous Air Pollutants By a Standardized Plant Canopy. Journal of the Air Pollution Control Association, 23, 203-206. https://doi.org/10.1080/00022470.1973.10469767

[22] Kadas, G. (2006) Rare Invertebrates Colonizing Green Roofs in London. Urban Habitats, 4, 66-86.

[23] Van Renterghem, T. (2018) Towards Explaining the Positive Effect of Vegetation on the Perception of Environmental Noise. Urban Forestry and Greening, 40, 133-144. https://doi.org/10.1016/j.ufug.2018.03.007

[24] Walters, S.A. and Midden, K.S. (2018) Sustainability of Urban Agriculture: Vegetable Production on Green Roofs. Agriculture, 8, 168.

https://doi.org/10.3390/agriculture8110168

[25] Grunewald, K., Richter, B., Meinel, G., Herold, H. and Syrbe, R.-U. (2017) Proposal of Indicators Regarding the Provision and Accessibility of Green Spaces for Assessing the Ecosystem Service "Recreation in the City" in Germany. International Journal of Biodiversity Science, Ecosystem Services \& Management, 13, 26-39. https://doi.org/10.1080/21513732.2017.1283361

[26] South Australian Department of Local Government and Planning (2010) Water Sensitive Urban Design Technical Manual for the Greater Adelaide Region, Government of South Australia, Adelaide.

https://www.sa.gov.au/topics/planning-and-property/land-and-property-developme nt/planning-professionals/water-sensitive-urban-design

[27] Bass, B., Krayenhoff, E.S., Martilli, A., Stull, R.B. and Auld, H. (2003) The Impact of Green Roofs on Toronto's Urban Heat Island. Proceedings of the First North 
American Green Roof Conference: Greening Rooftops for Sustainable Communities, Chicago, 20-30 May 2003, 292-304.

[28] Gaffin, S.R., Rosenzweig, C., Parshall, L., Beattie, D., Berghage, R., O’Keeffe, G. and Braman, D. (2005) Energy Balance Modeling Applied to a Comparison of Green and White Roof Cooling Efficiency. Third Annual Greening Rooftops for Sustainable Communities Conference, Washington DC, 4-6 May 2005.

[29] Vijayaraghavan, K. and Joshi, U.M. (2014) Can Green Roof Act as a Sink for Contaminants? A Methodological Study to Evaluate Runoff Quality from Green Roofs. Environmental Pollution, 194, 121-129. https://doi.org/10.1016/j.envpol.2014.07.021

[30] Vargas-Hernandez, J.G., Pallagst, K. and Hammer, P. (2018) Urban Green Spaces as a Component of an Ecosystem Functions, Services, Users, Community Involvement, Initiatives and Actions. International Journal of Environmental Sciences and Natural Resources, 8, Article ID: 555730.

[31] Williams, N., Lundholm, J. and McIvor, S. (2014) Do Green Roofs Help Urban Biodiversity Conservation? Journal of Applied Ecology, 51, 1643-1649. https://doi.org/10.1111/1365-2664.12333

[32] Ksiazek, K., Tonietto, R. and Ascher, J.S. (2014) Ten Bee Species New to Green Roofs in the Chicago Area. The Great Lakes Entomologist, 47, Article 13. https://scholar.valpo.edu/tgle/vol47/iss1/13

[33] Monterusso, M.A., Rowe, D.B. and Rugh, C.L. (2005) Establishment and Persistence of Sedum spp. and Native Taxa for Green Roof Applications. HortScience, 40, 391-396. https://doi.org/10.21273/HORTSCI.40.2.391

[34] Hoch, J.M., Rhodes, M.E., Shek, K.L., Dinwiddie, D., Hiebert, T.C., Gill, A.S., Salazar Estrada, A.E., Griffin, K.L., Palmer, M.I. and McGuire, K.L. (2019) Soil Microbial Assemblages Are Linked to Plant Community Composition and Contribute to Ecosystem Services on Urban Green Roofs. Frontiers in Ecology and Evolution, 7, 198. https://doi.org/10.3389/fevo.2019.00198

[35] Gedge, D. and Kadas, G. (2005) Green Roofs and Biodiversity. Biologist, 52, 161-169.

[36] Perkins, M. and Joyce, D. (2012) Living Wall and Green Roof Plants for Australia. Rural Industries Research and Development Corporation, Canberra.

[37] Osborne, J. and Wheeler, T. (2010) Green Roof Design Resource Manual. Environa Studio, Surry Hills, Sydney.

[38] Hopkins, G. and Goodwin, C. (2011) Living Architecture: Green Roofs and Walls. Collingwood. CSIRO Press, Collingwood, Victoria, Australia.

https://doi.org/10.1071/9780643103078

[39] Cantor, S.L. (2008) Green Roofs in Sustainable Landscape Design. W.W. Norton \& Company, New York.

[40] Hilten, R.N., Lawrence, T.M. and Tollner, E.W. (2008) Modelling Stormwater Runoff from Green Roofs with HYDRUS-1D. Journal of Hydrology, 358, 288-293. https://doi.org/10.1016/j.jhydrol.2008.06.010

[41] Kennedy, J., Haas, P. and Eyring, B. (2008) Measuring the Economic Impacts of Greening: The Center for Neighborhood Technology Green Values Calculator. In: Birch, E. and Wachter, S., Eds., Growing Greener Cities: Urban Sustainability in the Twenty-First Century, University of Pennsylvania Press, Philadelphia.

[42] Birch, E. and Wachter, S. (2008) Growing Greener Cities: Urban Sustainability in the Twenty-First Century. University of Pennsylvania Press, Pittsburgh. https://doi.org/10.9783/9780812204094 
[43] Getter, K.L. and Rowe, D.B. (2006) The Role of Extensive Green Roofs in Sustainable Development. HortScience, 41, 1276-1285. https://doi.org/10.21273/HORTSCI.41.5.1276

[44] Mentens, J., Raes, D. and Hermy, M. (2006) Green Roofs as a Tool for Solving the Rainwater Runoff Problem in the Urbanized 21st Century. Landscape and Urban Planning, 77, 217-226. https://doi.org/10.1016/j.landurbplan.2005.02.010

[45] Dunnett, N. and Kingsbury, N. (2004) Planting Green Roofs and Living Walls. Timber Press, Portland, OR.

[46] Santamouris, M., Pavlou, C., Doukas, P., Mihalakakou, G., Synnefa, A., Hatzibiros, A. and Patargias, P. (2007) Investigating and Analysing the Energy and Environmental Performance of an Experimental Green Roof System Installed in a Nursery School Building in Athens, Greece. Energy, 32, 1781-1788.

https://doi.org/10.1016/j.energy.2006.11.011

[47] Akbari, H. and Konopacki, S. (2005) Calculating Energy-Saving Potentials of Heat Island Reduction Strategies. Energy Policy, 33, 721-756. https://doi.org/10.1016/j.enpol.2003.10.001

[48] Hien, W.N. (2002) A Study of The Urban Heat Island In Singapore. Singapore National University. http://www.bca.gov.sg/ResearchInnovation/others/UHI\%20_2004-001_\%20rev.pdf

[49] Teemusk, A. and Mander, U. (2010) Temperature Regime of Planted Roofs Compared with Conventional Systems. Ecological Engineering, 36, 91-95. https://doi.org/10.1016/j.ecoleng.2009.09.009

[50] Chen, D. and Williams, N. (2009) Green Roofs as an Adaptation to Climate Change: Modelling the Green Roof at the Burnley Campus, the University of Melbourne. CAF R-00555-34-5-001. CSIRO, Melbourne.

[51] Fang, C.F. (2008) Evaluating the Thermal Reduction Effect of Plant Layers on Rooftops. Energy and Buildings, 40, 1048-1052. https://doi.org/10.1016/j.enbuild.2007.06.007

[52] Sailor, D.J. (2008) A Green Roof Model for Building Energy Simulation Programs. Energy and Buildings, 40, 1466-1478. https://doi.org/10.1016/j.enbuild.2008.02.001

[53] Takebayashi, H. and Moriyama, M. (2007) Surface Heat Budget on Green Roof and High Reflection Roof for Mitigation of Urban Heat Island. Building and Environment, 42, 2971-2979. https://doi.org/10.1016/j.buildenv.2006.06.017

[54] Nagase, A. and Tashiro-Ishii, Y. (2018) Habitat Template Approach for Green Roofs Using a Native Rocky Sea Coast Plant Community in Japan. Journal of Environmental Management, 206, 255-265. https://doi.org/10.1016/j.jenvman.2017.10.001

[55] Kyrö, K., Brenneisen, S., Kotze, D.J., Szallies, A., Gerner, M. and Lehvävirta, S. (2018) Local Habitat Characteristics Have a Stronger Effect than the Surrounding Urban Landscape on Beetle Communities on Green Roofs. Urban Forestry \& Urban Greening, 29, 122-130. https://doi.org/10.1016/j.ufug.2017.11.009

[56] Fulthorpe, R.R., MacIvor, J.S. and Yasui, S.-L.E. (2018) The Green Roof Microbiome: Improving Plant Survival for Ecosystem Service Delivery. Frontiers in Ecology and Evolution, 6, 5. https://doi.org/10.3389/fevo.2018.00005

[57] Aronson, M.F.J., Lepczyk, C.A., Evans, K.L., Goddard, M.A., Lerman, S.B., MacIvor, J.S., Nilon, C.H. and Vargo, T. (2017) Biodiversity in the City: Key Challenges for Urban Green Space Management. Frontiers in Ecology and Environment, 15, 189-196. https://doi.org/10.1002/fee.1480 
[58] New, T.R. (2016) Lepidoptera Conservation in Urban Environments: Theory and Practice. The Victorian Naturalist, 133, 160-164.

[59] Berthon, K., Nipperess, D., Davies, P. and Bulbert, M. (2015) Confirmed at Last: Green Roofs Add Invertebrate Diversity, State of Australian Cities Conference 2015. http://apo.org.au/node/63205

[60] Köhler, M. (2006) Long-Term Vegetation Research on Two Extensive Green Roofs in Berlin. Urban Habitats, 4, 3-26.

[61] Kuronuma, T., et al. (2018) $\mathrm{CO}_{2}$ Payoff of Extensive Green Roofs with Different Vegetation Species. Sustainability, 10, 2256. https://doi.org/10.3390/su10072256

[62] Burton, C. (2002) Roof gardens. In: Aitken, R. and Looker, M., Eds., The Oxford Companion to Australian Gardens, Oxford University Press, Melbourne, 514-515.

[63] Edwards, B. W. and Naboni, E. (2013) Green Buildings Pay: Design, Productivity and Ecology. 3rd Edition, Routledge, Oxford, UK. https://doi.org/10.4324/9780203082386

[64] Kazmierczak, A. and Carter, J. (2010) Chicago: Green Permit Program-Incentives for Developers to Install Green Roofs.

http://resources.cleanenergyroadmap.com/BENV_Z_chicago-green-roofs-permit-p rogram.pdf

[65] Hunter, A.M., et al. (2014) Quantifying the Thermal Performance of Green Facades: A Critical Review. Ecological Engineering, 63, 102-113. https://doi.org/10.1016/j.ecoleng.2013.12.021

[66] Morris, C. (2011) Rooftop Garden Trial. University of Western Sydney, Sydney.

[67] Wilkinson, S., Rose, C., Glenis, V. and Lamond, J. (2014) Modelling Green Roof Retrofit in the Melbourne Central Business District. In: Proverbs, D. and Brebbia, C., Eds., Flood Recovery, Innovation and Response IV, WIT Press, Ashurst, UK. https://doi.org/10.2495/FRIAR140111

[68] Wilkinson, S., James, K. and Reed, R. (2009) Using Building Adaptation to Deliver Sustainability in Australia. Structural Survey, 27, 46-61.

https://doi.org/10.1108/02630800910941683

[69] Wilkinson, S., Ghosh, S. and Page, L. (2013) Options for Green Roof Retrofit and Urban Food Production in the Sydney CBD. Construction and Building Research Conference of the Royal Institution of Chartered Surveyors, New Delhi, India.

[70] City of Sydney (2014) Green Roofs and Walls Policy. City of Sydney, Australia. http://www.cityofsydney.nsw.gov.au/vision/towards-2030/sustainability/greening-t $\underline{\text { he-city/green-roofs-and-walls\#page-element-dload }}$

[71] City of Sydney (2014) Green Roofs and Walls Policy Implementation Plan. City of Sydney, Australia. http://www.cityofsydney.nsw.gov.au/vision/towards-2030/sustainability/greening-t he-city/green-roofs-and-walls\#page-element-dload

[72] City of Melbourne (2012) Create Green Roofs, Walls and Facades. https://www.melbourne.vic.gov.au/community/greening-the-city/green-infrastructu re/Pages/green-roofs-walls-facades.aspx

[73] Victorian Department of Sustainability (2014) The Growing Green Guide: A Guide to Green Roofs, Walls and Facades in Melbourne and Victoria. https://www.growinggreenguide.org/wp-content/uploads/2014/02/growing_green guide_ebook_130214.pdf

[74] City of Melbourne (2017) Green Our City Strategic Action Plan 2017-2021: Vertical and Rooftop Greening in Melbourne. Victoria, Melbourne. 
https://www.melbourne.vic.gov.au/community/greening-the-city/green-infrastructu re/Pages/green-our-city-action-plan.aspx

[75] South Australian Department of Planning, Transport and Infrastructure (2012) Development Plan, Adelaide (City). Government of South Australia, Adelaide, Australia.

https://www.sa.gov.au/topics/planning-and-property/development-plans/greater-m etropolitan-adelaide-development-plans/adelaide-city-development-plan

[76] Brisbane City Council (2007) Plan for Action on Climate Change and Energy. https://www.joondalup.wa.gov.au/files/councilmeetings/2007/Attach5brf180907.pdf

[77] City of South Perth (2013) Strategic Direction 2-Environment: Policy P211 Water Sensitive Urban Design.

https://southperth.wa.gov.au/docs/default-source/6-about-us/council/policies-deleg ations/envirnoment/p211-water-sensitive-urban.pdf?sfvrsn=b6f6fabd_6

[78] City of Darwin, Northern Territory Government and the Australian Government (2015) City Centre Master Plan. City of Darwin.

[79] Australian Capital Territory Government (2018) Canberra's Living Infrastructure: Information Paper. ACT Government, Canberra.

[80] Daly, G.C., Alexander, S., Ehrlich, P.R., Goulder, L., Lubchenco, J., Matson, P.A. and Mooney, H.A. (1997) Ecosystem Services: Benefits Supplied to Human Societies by Natural Ecosystems. Issues in Ecology, 2, 2-16.

[81] Costanza, R., de Groot, R., Sutton, P., van der Ploeg, S., Anderson, S. J., Kubiszewski, I., Farber, S. and Turner, R.K. (2014) Changes in the Global Value of Ecosystem Services. Global Environmental Change-Human and Policy Dimensions, 26, 152-158. https://doi.org/10.1016/j.gloenvcha.2014.04.002

[82] Davis, M.F. and Svenning, J.-C. (2018) Mammal Diversity Will Take Millions of Years to Recover from the Current Biodiversity Crisis. Proceedings of the National Academy of Sciences of the United States of America, 115, 11262-11267. https://doi.org/10.1073/pnas.1804906115

[83] Evans, M.J., Banks, S.C., Driscoll, D.A., Hicks, A.J., Melbourne, B.A. and Davies, K.F. (2016) Short- and Long-Term Effects of Habitat Fragmentation Differ but Are Predicted by Response to the Matrix. Ecology, 98, 807-819.

https://doi.org/10.1002/ecy.1704

[84] Lewis, S.L. and Maslin, M.A. (2015) Defining the Anthropocene. Nature, 519, 171-180. https://doi.org/10.1038/nature14258

[85] Novacek, M.J. and Cleland, E.E. (2001) The Current Biodiversity Extinction Event: Scenarios for Mitigation and Recovery. Proceedings of the National Academy of Sciences of the United States of America, 98, 5466-5470. https://doi.org/10.1073/pnas.091093698

[86] Hughes, A.R., Grabowski, J.H., Leslie, H.M., Scyphers, S. and Williams, S.L. (2018) Inclusion of Biodiversity in Habitat Restoration Policy to Facilitate Ecosystem Recovery. Conservation Letters, 11, e12419. https://doi.org/10.1111/conl.12419

[87] Davies, P., Corkery, L., Nipperess, D., Barnett, G., Bishop, M., Hochuli, D., Hose, G., Joei, L.C., Lin, B., Keane, A., Osmond, P., Pelleri, N., Staas, L., Threlfall, C., Van den Berg, F. and Wilkinson, S. (2017) Blueprint for Living Cities: Policy to Practice. National Green Infrastructure Network.

https://www.environment.nsw.gov.au/resources/grants/blueprint-living-cities-polic y-practice.pdf

[88] Braaker, S., Ghazoul, J., Obrist, M.K. and Moretti, M. (2014) Habitat Connectivity 
Shapes Urban Arthropod Communities: The Key Role of Green Roofs. Ecology, 95, Issue 4. https://doi.org/10.1890/13-0705.1

[89] Gabrich, M., Kotze, J. and Lehvavirta, S. (2016) Substrate Depth and Roof Age Strongly Affect Plant Abundances on Sedum-Moss and Meadow Green Roofs in Helsinki, Finland. Ecological Engineering, 86, 95-104.

https://doi.org/10.1016/j.ecoleng.2015.10.022

[90] Madre, F., Vergnes, A., Machon, N. and Clergeau, P. (2014) Green Roofs as Habitats for Wild Plant Species in Urban Landscapes: First Insights from a Large-Scale Sampling. Landscape and Urban Planning, 122, 100-107. https://doi.org/10.1016/j.landurbplan.2013.11.012

[91] Landolt, E. (2001) Orchideen-Wiesen in Wollishofen (Zürich): Ein erstaunliches Relikt aus dem Anfang des 20. Jahrhunderts. Vierteljahresschrift der Naturforschenden Gesellschaft in Zürich, 146, 41-51.

[92] Snep, R.P.H., WallisDeVries, M.F. and Opdam, P. (2011) Conservation Where People Work: A Role for Business Districts and Industrial Areas in Enhancing Endangered Butterfly Populations? Landscape and Urban Planning, 103, 94-101. https://doi.org/10.1016/j.landurbplan.2011.07.002

[93] Wilson, E.O. (2010) The Diversity of Life. Belknap Press of Harvard University Press, Cambridge, MA.

[94] Margules, C.R. and Pressey, R.L. (2000) Systematic Conservation Planning. Nature, 405, 243-253. https://doi.org/10.1038/35012251

[95] McKinney, M.L. (2002) Urbanization, Biodiversity, and Conservation. BioScience, 52, 883-890. https://doi.org/10.1641/0006-3568(2002)052[0883:UBAC]2.0.CO;2

[96] Collinge, S.K. (1996) Ecological Consequences of Habitat Fragmentation: Implications for Landscape Architecture and Planning. Landscape and Urban Planning, 36, 59-77. https://doi.org/10.1016/S0169-2046(96)00341-6

[97] Goddard, M.A., Dougill, A.J. and Benton, T.G. (2010) Scaling up from Gardens: Biodiversity Conservation in Urban Environments. Trends in Ecology \& Evolution, 25, 90-98. https://doi.org/10.1016/j.tree.2009.07.016

[98] Downton, P., Jones, D., Zeunert, J. and Roos, P. (2017) Biophilic Design Applications: Theory and Patterns into Built Environment Education. Frontiers in Ecology and Evolution, Dubai, UAE, 59-65. https://doi.org/10.18502/keg.v2i2.596

[99] Kellert, S.R. (1993) The Biological Basis for Human Values of Nature. In: Kellert, S.R. and Wilson, E.O., Eds., The Biophilia Hypothesis, Island Press, Washington DC, 42-69.

[100] Kowarik, I. (2011) Novel Urban Ecosystems, Biodiversity, and Conservation. Environmental Pollution, 159, 1974-1983. https://doi.org/10.1016/j.envpol.2011.02.022

[101] Braaker, S., Ghazoul, J., Obrist, M.K. and Moretti, M. (2014) Habitat Connectivity Shapes Urban Arthropod Communities: The Key Role of Green Roofs. Ecology, 95, 1010-1021. https://doi.org/10.1890/13-0705.1

[102] Blank, L., Vasl, A., Levy, S., Grant, G., Kadas, G., Dafni, A. and Blaustein, L. (2013) Directions in Green Roof Research: A Bibliometric Study. Building and Environment, 66, 23-28. https://doi.org/10.1016/j.buildenv.2013.04.017

[103] Beier, P. and Noss, R. (1998) Do Habitat Corridors Provide Connectivity? Conservation Biology, 12, 1241-1252. https://doi.org/10.1046/j.1523-1739.1998.98036.x

[104] Osmond, P. and Blair, J. (2016) Green Roof Retrofitting and Conservation of Endangered Flora. In: Wilkinson, S.J. and Dixon, T., Eds., Green Roof Retrofit. Building Urban Resilience, Wiley-Blackwell, Oxford, 140-157. 
https://doi.org/10.1002/9781119055587.ch8

[105] Naveh, Z. and Lieberman, A.S. (1990) Landscape Ecology, Theory and Application. Springer-Verlag, New York. https://doi.org/10.1007/978-1-4757-4082-0

[106] Osmond, P. (1994) Environmental Sustainability and Inner-Urban Landscape Design. A Vision for a Greener City. National Greening Australia Conference, Fremantle, 4-6 October.

[107] Francis, R. and Lorimer, J. (2011) Urban Reconciliation Ecology: The Potential of Living Roofs and Walls. Journal of Environmental Management, 92, 1429-1437. https://doi.org/10.1016/j.jenvman.2011.01.012

[108] MacIvor, J.S. and Lundholm, J. (2011) Performance Evaluation of Native Plants Suited to Extensive Green Roof Conditions in a Maritime Climate. Ecological Engineering, 37, 407-417. https://doi.org/10.1016/j.ecoleng.2010.10.004

[109] Brenneisen, S. (2006) Space for Urban Wildlife: Designing Green Roofs as Habitats in Switzerland. Urban Habitats, 4, 27-36.

[110] Grant, G. (2006) Extensive Green Roofs in London. Urban Habitats, 4, 51-65.

[111] Washburn, B.E., Swearingin, R.M. and Pullins, C.K. (2016) Composition and Diversity of Avian Communities Using a New Urban Habitat: Green Roofs. Environmental Management, 57, 1230-1239. https://doi.org/10.1007/s00267-016-0687-1

[112] Lundholm, J.T. and Richardson, P.J. (2010) Habitat Analogues for Reconciliation Ecology in Urban and Industrial Environments. Journal of Applied Ecology, 47, 966-975. https://doi.org/10.1111/j.1365-2664.2010.01857.x

[113] Nagase, A. and Dunnett, N. (2012) Amount of Water Runoff from Different Vegetation Types on Extensive Green Roofs: Effects of Plant Species, Diversity and Plant Structure. Landscape and Urban Planning, 104, 356-363. https://doi.org/10.1016/j.landurbplan.2011.11.001

[114] Sutton, R.K., Harrington, J.A., Skabelund, L., MacDonagh, P., Coffman, R.R. and Koch, G. (2012) Prairie-Based Green Roofs: Literature, Templates, and Analogs. Journal of Green Building, 7, 143-172. https://doi.org/10.3992/jgb.7.1.143

[115] Alam, H., Khattak, J.Z.K., Ppoyil, S.B.T., Kurup, S. and Ksiksi, T.S. (2017) Landscaping with Native Plants in the UAE: A Review. Emirates Journal of Food and Agriculture, 29, 729-741. https://doi.org/10.9755/ejfa.2017.v29.i10.319

[116] Ishimatsu, K. and Ito, K. (2013) Brown/Biodiverse Roofs: A Conservation Action for Threatened Brownfields to Support Urban Biodiversity. Landscape and Ecological Engineering, 9, 299-304. https://doi.org/10.1007/s11355-011-0186-8

[117] Wintle, B. and Bekessy, S. (2018) The Small Patch of Bush over Your Back Fence Might Be Key to a Species' Survival. The Conversation, Australia, 13 December 2018.

[118] Van Mechelen, C., Van Meerbeek, K., Dutoit, T. and Hermy, M. (2015) Functional Diversity as a Framework for Novel Ecosystem Design: The Example of Extensive Green Roofs. Landscape and Urban Planning, 136, 165-173. https://doi.org/10.1016/j.landurbplan.2014.11.022

[119] Kraft, A. (2013) Why Manhattan's Green Roofs Don't Work-And How to Fix Them. Scientific American, 17 May 2013.

[120] Oberndorfer, E., Lundholm, J., Bass, B., Coffman, R.R., Doshi, H., Dunnett, N., Gaffin, S., Köhler, M., Liu, K.K.Y. and Rowe, B. (2007) Green Roofs as Urban Ecosystems: Ecological Structures, Functions, and Services. BioScience, 57, 823-833. https://doi.org/10.1641/B571005

[121] Livingroofs.org 2019. London 2019 Green Roof Report. 
https://livingroofs.org/biodiversity-and-wildlife/

[122] Nagase, A. and Dunnett, N. (2011) The Relationship between Percentage of Organic Matter in Substrate and Plant Growth in Extensive Green Roofs. Landscape and Urban Planning, 103, 230-236. https://doi.org/10.1016/j.landurbplan.2011.07.012

[123] Orians, G.H. and Milewski, A.V. (2007) Ecology of Australia: The Effects of Nutrient-Poor Soils and Intense Fires. Biological Reviews, 82, 393-423. https://doi.org/10.1111/j.1469-185X.2007.00017.x

[124] McGuire, K.L., Payne, S.G., Palmer, M.I., et al. (2013) Digging the New York City Skyline: Soil Fungal Communities in Green Roofs and City Parks. PLoS ONE, 8, e58020. https://doi.org/10.1371/journal.pone.0058020

[125] Hoch Jessica, M.K., Rhodes Matthew, E., Shek Kaye, L., Devin, D., Hiebert Terra, C., Gill Aman, S., Salazar Estrada Andrés, E., Griffin Kevin, L., Palmer Matthew, I. and McGuire Krista, L. (2019) Soil Microbial Assemblages Are Linked to Plant Community Composition and Contribute to Ecosystem Services on Urban Green Roofs. Frontiers in Ecology and Evolution.

https://doi.org/10.3389/fevo.2019.00198

[126] NSW Scientific Committee (2002) Eastern Suburbs Banksia Scrub in the Sydney Basin Bio-Region: Endangered Ecological Community Listing, Final Determination. NSW Scientific Committee, Sydney.

[127] Perkins, I., Diamond, J., SanRoque, G., Raffan, L., Digby, B., Jensen, P. and Hirschfeld, D. (2012) Eastern Suburbs Banksia Scrub: Rescuing an Endangered Ecological Community. Ecological Management and Restoration, 13, 224-237.

https://doi.org/10.1111/emr.12002

[128] NSW Office of Environment and Heritage (2018) Saving Our Species. http://www.environment.nsw.gov.au/topics/animals-and-plants/threatened-species/ about-threatened-species/threatened-populations

[129] Bradstock, R.A., et al. (1995) Fire and Conservation: Imperatives and Constraints on Managing for Diversity. In: Bradstock, R.A., Auld, T.D., Keith, D.A., Kingsford, R.T., Lunney, D. and Sivertsen, D.P., Eds., Conserving Biodiversity: Threats and Solutions, NSW National Parks and Wildlife Service, Sydney, 323-333.

[130] NSW Office of Environment and Heritage (2017) Review of Environmental Factors: Bundeena Coast Eco-Lodge Request Alternative Right of Way. Prepared by RVA Australia Pty Ltd. for NSW OEH.

https://www.environment.nsw.gov.au/-/media/OEH/Corporate-Site/Documents/Pa rks-reserves-and-protected-areas/Parks-management-other/review-environmental-f actors-bundeena-coast-eco-lodge-request-alternative-right-way-160446.pdf

[131] Dunlop, M., Ryan, P., McGuinness, S. and Glynn, A. (2017) Scoping Climate-Ready Management of Eastern Suburbs Banksia Scrub in Queens Park, Sydney. CSIRO. http://www.sydneycoastalcouncils.com.au/sites/default/files/ESBS\%20Climate\%20r eady\%20analysis\%20and\%20business\%20case.pdf

[132] Pellow, B., Lambert, J. and Lambert, G. (2015) Impacts of Fire, Thinning and Herbivory on Species Diversity in Eastern Suburbs Banksia Scrub. Ecology Consulting, 3, 25-26.

[133] Perkins, I. and McDonald, T. (2012) Speaking Multiple Languages: Practice, Management and Ecology. Interview with Ian Perkins. Ecological Management and Restoration, 13, 126-134. https://doi.org/10.1111/j.1442-8903.2012.00652.x

[134] Pallin, N. (2000) Ku-Ring-Gai Flying Fox Reserve Habitat Restoration Project, 15 Years on. Ecological Management and Restoration, 1, 10-20.

https://doi.org/10.1046/j.1442-8903.2000.00003.x 
[135] NSW Department of Environment and Conservation (DEC) (2004) Eastern Suburbs Banksia Scrub Endangered Ecological Community Recovery Plan. NSW DEC, Sydney.

[136] Tozer, M.G. and Bradstock, R.A. (2002) Fire-Mediated Effects of Over Storey on Plant Species Diversity and Abundance in an Eastern Australian Heath. Plant Ecology, 164, 213-223. https://doi.org/10.1023/A:1021387210745

[137] Huang, Y., Ma, Y., Wu, W. and Lv, Q. (2017) Applying Biotope Concepts and Approaches for Sustainable Environmental Design. Korean Journal of Civil Engineering, 21, 1614-1622. https://doi.org/10.1007/s12205-016-1077-1

[138] Razzaghmanesh, M., Beecham, S. and Kazemi, F. (2014) The Growth and Survival of Plants in Urban Green Roofs in a Dry Climate. Science of the Total Environment, 476-477, 288-297. https://doi.org/10.1016/j.scitotenv.2014.01.014

[139] Gorelick, R. (2006) Combining Richness and Abundance into A Single Diversity Index Using Matrix Analogues of Shannon's and Simpson's Indices. Ecography, 29, 525-530. https://doi.org/10.1111/j.0906-7590.2006.04601.x

[140] Magurran, A.E. (2013) Ecological Diversity and Its Measurement. Springer, Netherlands. 